\title{
Fenomenologisk forståelse av elevens bevegelsesaktivitet - et bidrag til innsikt i lærerens tolkningsarbeid $i$ kroppsøvingsundervisningen
}

\author{
Idar Lyngstad ${ }^{\star}$ \\ Nord Universitet, Levanger, Norge
}

\begin{abstract}
Sammendrag
I denne studien er kroppsøvingslæreres tolkning av elevers bevegelsesaktivitet og -opplevelse i kroppsøvingstimene drøftet innenfor en kroppsfenomenologisk teoriramme. Spørsmålet som er blitt stilt er: På hvilken måte kan kroppsfenomenologiske begreper bidra til å utdype denne tolkningsprosessen, og i videre sammenheng belyse faglig-didaktiske perspektiver i kroppsøving? Denne drøftingen, som baserer seg på relevante litteraturbidrag fra et kroppsfenomenologisk forskningsområde, kommer fram til at teori fra dette feltet belyser at læreren koordinerer egne didaktiske handlinger i tråd med elevens bevegelsesaktivitet, og persiperer, tolker og forstår elevens bevegelsesaktivitet og -opplevelse giennom egne handlinger i undervisningen. Trådene mellom didaktiske handlinger og elevens atferd kan imidlertid bli løsere sammenvevd fordi den sosiale interaksjonen i undervisningen skjer så raskt at det lærere husker fra timene, blandes med gjetninger. Dette indikerer at tolkningsprosessen er kompleks, og at utfallet av den ikke er pålitelig $i$ alle tilfeller. Teori om tolkning og innlevelse må dessuten presiseres på et viktig punkt, fordi innlevelsen i elevens livsverden kan aldri bli total. En kan aldri ende opp med å bli den andre. På den annen side er ikke forskjellen mellom lærer og elev en ufullkommenhet eller mangel, den er derimot konstitusjonell og til nytte i det videre arbeid med innsikter i tolkningsprosessen, noe som diskuteres i tilknytning til begrepene kroppslig resonans, kinestetisk sammenfletting og lærerens patiske kunnskap i studien.
\end{abstract}

Nøkkelord: Kroppsøvingslerer; bevegelsesopplevelse; tolkning; kroppslig resonans; kinestetisk sammenfletning; kroppsfenomenologi; patisk kunnskap

Received: January, 2017; Accepted: June, 2017; Published: October, 2017

\begin{abstract}
In this study, the physical education (PE) teacher's interpretation on the pupil's movement experience is examined within a phenomenological theory framework. The research question is: In what
\end{abstract}

${ }^{\star}$ Correspondence to: Idar Lyngstad, Nord Universitet, Postboks 93, 7601 Levanger. Email: idar.k.lyngstad@nord.no

(C) 2017 I. Lyngstad. This is an Open Access article distributed under the terms of the Creative Commons Attribution 4.0 International License (http://creativecommons.org/licenses/by/4.0/), allowing third parties to copy and redistribute the material in any medium or format and to remix, transform, and build upon the material for any purpose, even commercially, provided the original work is properly cited and states its license.

Citation: I. Lyngstad. "Fenomenologisk forståelse av elevens bevegelsesaktivitet - et bidrag til innsikt i larerens tolkningsarbeid $i$ kroppsøvingsundervisningen". Fournal for Research in Arts and Sports Education, Vol. 1, 2017, pp. 1-15. http://dx.doi. 
way may phenomenological terms and theory elaborate the teacher's interpretation process, and further examine pedagogical perspectives in PE. The analysis, which is based on relevant literature from a phenomenological research area, shows that phenomenological theory elaborates that the teacher coordinates his own pedagogical actions in thread of the pupil's movements and perceives, interprets and understands the pupil's movement experience. However, these threads might not be tightly interwoven at all times, because social interaction happens so fast in PE that the teacher's memories from what goes on in PE-lessons are mixed with guessing. Theory of interpretation and understanding must be limited at a critical point, because the insight into the pupil's lifeworld can never be total. On the other hand, the difference is not an imperfection, or drawback, it is constitutional for deeper understanding of the interpretation process, which is discussed in terms of perception, bodily resonance, kineasthetic intertwinement and the teacher's pathic knowledge in the study.

Keywords: Physical education teacher; movement experience; interpretation; phenomenology; bodily resonance; kineasthetic intertwinement; pathic knowledge

\section{Innledning}

Kroppsøving i skolen består av allsidig bevegelsesopplæring, og i læreplanen i faget er det et sentralt mål at eleven skal oppleve glede og inspirasjon ved kroppslig bevegelseslæring og ved å være fysisk aktiv (Utdanningsdirektoratet, 2015). Faget skal bidra til at elevene opplever bevegelsesglede og inspirasjon i forbindelse med ulike former for leik, idrett og dans. Elevens bevegelsesglede og -opplevelse vil imidlertid variere i timene, og læreren må, i tillegg til å bruke muligheten til å snakke direkte med elevene, tolke elevens bevegelsesaktivitet for å kunne bedømme om eleven opplever noe positivt eller negativt i forbindelse med aktiviteten.

Denne tolkningsprosessen er relativt lite belyst i forskningslitteraturen, selv om forskere på det kroppsøvingspedagogiske området i senere år har tatt i bruk ulike teoretiske innsikter og fordypet studiene om lærerens undervisningspraksis i ganske mange teoretiske perspektiver, blant annet i kroppsfenomenologi (Lloyd \& Smith, 2006; Lyngstad, 2013; Lyngstad, 2014; Standal, 2015). I kroppsfenomenologisk litteratur er det blitt beskrevet at lærerens tolkning kan svinge mellom en individualisert prosess og en dyp felles og delt prosess, som absorberer elevens erfaring og opplevelse, til nytte for det pedagogiske arbeidet (Lloyd \& Smith, 2006). I den individualiserte prosessen blir ikke lærerens tolkningsprosess sammenflettet med elevens bevegelsesaktivitet, mens dette skjer i større grad i den felles og delte prosessen. Læreren fornemmer elevens bevegelsesaktivitet nærmest som om han eller hun utfører aktiviteten selv, gjennom en delt, felles opplevelse. Dette skjer fordi læreren kjenner til viktige elementer ved kroppslig bevegelse, som eleven utfører, og læreren fornemmer elevens sansing og følelse av bevegelse i tid og rom, rytme og bevegelseskrefters virkning. Dette bidrar ifølge Lloyd og Smith (2006) til en kinestetisk sammenfletting, som gir en spesiell fysisk og motorisk innlevelse og forståelse av elevens aktivitet og læringsprosess.

I annen kroppsfenomenologisk litteratur beskrives at læreren legger merke til, tolker og forstår elevens atferd i kroppsøvingstimene slik læreren ser at atferden utvikler seg over tid, som består av både fortid, nåtid og framtid (Lyngstad, 2014). Læreren 
persiperer elevens atferd i timene og ser og forstår atferden innenfor en ramme av historie som lages av læreren og eleven i fellesskap. Historiene er ikke først og fremst om hva som foregår i deres hoder, men om hva som foregår i deres felles, delte verden, og om hvordan de forstår og responderer på det som foregår i denne verden, som er preget av kroppslig bevegelse i mange variasjoner. Erfarne lærere kan persipere og bedømme elevens bevegelsesopplevelse på relativt kort tid, om den oppleves negativ, positiv eller litt av begge deler, samt på hvilken måte den varierer (Lyngstad, 2013). Samtidig reflekterer læreren over disse situasjonene i ettertid og belegger dem med opptil flere lag av mening, ikke bare om elevens opplevelse, men også om valg av aktivitet og undervisningsmetode opp imot elevens læring. Lærerens forståelse av elevens bevegelsesaktivitet og -opplevelse flettes med andre ord sammen med egen praksisteori (Orlikowski, 2010), som er utspunnet av egne refleksjoner både i og over undervisningssituasjoner.

Fra faglig-didaktisk ståsted er det relevant å studere lærerens tolkning av elevens bevegelsesaktivitet og -opplevelse i undervisningen i kroppsøving. Jeg har funnet det interessant å undersøke tolkningsprosessen innenfor en kroppsfenomenologisk teoriramme, både med tanke på utdypning $\mathrm{i}$ et teoretisk-fenomenologisk felt og for å belyse faglig-didaktiske perspektiver. Og spørsmålet som jeg har stilt, er følgende: På hvilken måte kan kroppsfenomenologiske begreper bidra til å utdype tolkningsprosessen - og i videre sammenheng belyse faglig-didaktiske perspektiver i kroppsøving?

Videre vil jeg gjøre rede for et sentralt grunnlag for studien, som omhandler at læreren står midt i et komplekst sosial-interaksjonistisk felt overfor elevene i kroppsøvingsundervisningen, samt den kroppsfenomenologiske teoriramme for analysen. Jeg vil også forklare kort omkring valg av litteratur fra det kroppsfenomenologiske forskningsområdet.

\section{Sosial interaksjon med mange elever på samme tid}

En viktig del av grunnlaget for studien er forskning som viser at læreren normalt må håndtere sosial interaksjon med mange elever på samme tid i undervisningen, og må fange opp sosiale signaler og beskjeder i relativt stort omfang fra elevene, samtidig som han eller hun organiserer, instruerer, forklarer og gir tilbakemeldinger til elevene i timene (Lyngstad, 2014). Noen ganger vil det være enkelt å se at elevene opplever glede eller skuffelse $i$ forbindelse med aktivitetene de deltar i, ettersom disse følelsene uttrykkes åpent og direkte av elevene. Elevene kan vise høy innsats, og de kan uttrykke på en tydelig måte at de for eksempel har det gøy, samtidig som på de på en annen side også kan uttrykke skuffelse og negativ bevegelsesopplevelse på en tydelig måte når de opplever dette (Lyngstad, 2010).

Men noen elever vil forsøke å skjule hva de føler og tenker, spesielt når noe oppleves som vanskelig (Hagen, Aune \& Lyngstad, 2014). Da kan det bli krevende å tolke og forstå hva de erfarer og opplever i timene. Slike elever kan være tilbøyelige til å manipulere situasjoner i undervisningen, for eksempel ved å skylde på at de er indisponert for fysisk aktivitet, eksempelvis syk eller skadet. De kan benytte «a strategic manipulation of a situation in such a way that an individual can claim that 
obstacles to her or his performance account for a potential failure» (Ommundsen, 2004, s. 183). Disse elevene kan dessuten ha vanskelig for å se seg selv i et positivt lys i kroppsøvingen, og kan havne utenfor mye av det sosiale samspillet i timene (Lyngstad, 2016). De ønsker gjerne å ikke tape ansikt, verken faglig eller sosialt. Samtidig vil det gjerne være slik at læringsprosessen også blir hemmet for disse elevene.

På den annen side kan læreren selv skape handlinger av denne typen gjennom sin undervisningspraksis. Lærerens valg av aktiviteter og undervisningsmåter vil påvirke eleven - og elevens (foretrukne) handlinger - $\mathrm{i}$ timene. Læreren påvirker elevens handlinger (og læringsprosess) i kraft av den formelle posisjonen læreren har gjennom sin faglige og didaktiske kompetanse (Lyngstad, 2016). Dette kan gi både positive og negative utslag (Aasland, Walseth \& Engelsrud, 2016). Det læreren skal tolke, kan med andre være skapt av læreren selv i større eller mindre grad, ut i fra lærerens instruksjoner og beskjeder.

Det vil altså være viktig å ha klart for seg at læreren kan være motivator, tilrettelegger og pådriver til læringsaktivitet på en positiv måte, men på den annen siden også være den som bidrar i en motsatt retning, til å virke demotiverende og gi eleven negativ erfaring og opplevelse av bevegelsesaktivitet. For eksempel kan harde, anstrengende øvelser brukes i (minst) to betydninger av læreren; i en positiv betydning, der læreren formidler - og møtes med forståelse fra eleven av at treningen gir god fysisk form og helse, men også en i negativ - og paradoksal - betydning, der øvelsene brukes som straff for elever som avbryter lærerens instruksjon i timen eller for elever som taper i konkurranser i undervisningen (Aasland, et al., 2016). En lærer kan altså bidra til å gi eleven negativ erfaring og opplevelse ved å kommandere eleven til å gjennomføre «straffeeksersis» i timen, eller beordre til harde, anstrengende øvelser etter at et nederlag i en konkurranse er et faktum. I det første tilfellet brukes straffeeksersis for å disiplinere eleven, mens i det andre tilfellet brukes øvelsene som straff etter tap i konkurranser i timene.

\section{Den kroppsfenomenologiske teoriramme}

Det er også viktig å ha klart for seg at denne sosiale interaksjonen kan engasjere følelser av ulike slag hos de involverte. Lærerens persepsjon og tolkning involverer følelser, som innenfor en kroppsfenomenologisk teoriramme kan forstås og beskrives på en bestemt måte (på samme måte vil elevens persepsjon og tolkning av lærerens undervisningsaktivitet engasjere følelser hos eleven). I følge Fuchs (2016) kan utviklingen av en følelse i tilknytning til sosial interaksjon defineres som former for kroppslig resonans. Dette omfatter følelser som for eksempel glede, tilfredshet, skuffelse, irritasjon eller spenning. Med kroppslig resonans menes nærmere bestemt en sentripetal resonans, for eksempel i form av rødming og skamfølelse, eller en sentrifugal resonans, som setter mennesket i handlingsberedskap. Det kan også bety at mennesket faktisk handler i sosiale situasjoner, for eksempel gjemmer seg, unngår oppmerksomhet fra andre, eller forholder seg passiv. I sosial interaksjon blir følelser ofte synlige i kroppslige uttrykk, væremåter og atferd, gjerne som symboler for en 
eller annen mening eller standpunkt, eller antydninger til handling av ett eller annet slag. Dette forklares ved at:

Our body is affected by the other's expression, and we experience the kinetics and intensity of his emotions through our own bodily kinaesthesia and sensation. Our body schemas and feelings expand and 'incorporate' the perceived body of the other. This creates a dynamic interplay, which forms the basis of social understanding and empathy (Fuchs, 2016, s. 198).

Den kroppsfenomenologiske teoriramme for studien bygger forørvig på Merleau-Pontys verk Phénoménologie de la perception (1945). Merleau-Ponty (1908-1961) presenterte i sitt verk sitt syn på at individet har, eller er i, et preobjektivt forhold til omverden (Østerberg, 1994). Med dette menes at individet sanser objekter i et perseptuelt felt, ved at det pre-objektivt erfarte $\mathrm{i}$ bevisstheten former seg og blir til noe avgrenset, noe annet enn det opprinnelige, det pre-objektivt erfarte. Dette er en prosess som forstås som en skiftning fra noe som er pre-objektivt erfart til det objektivt erfarte, og det tilsvarer et endring av bevissthetsform, fra før-refleksiv til refleksiv bevissthet. I en før-refleksiv bevissthet erfarer individet det preobjektive felt av fenomener, mens når refleksjonen inntrer, blir de pre-objektive fenomener til objekter.

Merleau-Ponty's teori tilsier at kroppen, som har ulike sanseorganer som brukes i persepsjonen, ikke er noe fysisk objekt, men heller er en enhet, eller syntese, der kroppens deler står i et indre og helhetlig forhold til hverandre. Kroppen er ikke en sammenstilling av vilkårlige deler (Swartling Widerström, 2005). Det spesielle er at kroppen - syntesen - er intensjonal og framkaster muligheter for individet og prosjekterer kommende handlinger. Menneskets persepsjon inngår i slike helhetlige prosjekter. I denne sammenheng finnes ikke enkeltstående, atomære persepsjoner, men en forestilling om at all persepsjon foregår på en bakgrunn, det vil si at persepsjonen er strukturert mot en bakgrunn. Persepsjonen forstås å være en egenskap som gjør at et menneske har kontakt med seg selv og med fortid, nåtid og framtid og gir perspektiv på verden omkring. For læreren i kroppsøving gjør persepsjonen at den profesjonelle verden viser seg og blir tilgjengelig for læreren og skaper vilkår for tilværelse som kroppslig subjekt i timene og til å forholde seg til andre, for eksempel eleven, i kroppsøvingsmiljøet. I denne livsverden eksisterer den profesjonelle verden som hver lærer har direkte tilgang til, og den inneholder alle former for pedagogiske handlinger og levd profesjonell erfaring, deriblant erfaring fra sosial interaksjon med elevene (Lyngstad, 2013). Herunder inngår tolkning av elevens bevegelsesaktivitet og -opplevelse i kroppsøvingstimene.

Forskere har i senere tid kommet med bidrag i forskningslitteraturen som har videreutviklet det kroppsfenomenlogiske perspektivet på det pedagogiske området i kroppsøvingsforskningen. Her nevnes spesielt Standal (2015), som har utgitt «Phenomenology and Pedagogic in Physical Education». Andre bidragsytere er Swartling Widerstrøm (2005) og Lyngstad (2013). Til en viss grad har forskningen undersøkt tolkningsprosesser i kroppsøvingsundervisningen, f. eks. Lloyd og Smith (2006) og Lyngstad (2014), som er nevnt, men det er foretatt relativt få studier som har rettet 
fokuset på lærerens persepsjon og tolkning. Jeg har valgt litteratur som delvis belyser denne prosessen på en generell måte (Gallagher \& Zahavi, 2008; Steinsholt, 2004; Crossley, 1996, Fuchs, 2016), men som også belyser persepsjon og tolkning avgrenset innenfor et kroppsøvingsområde (Arnold, 1979; Standal, 2015; Smith \& Lloyd, 2006; Lyngstad, 2014). Alle litteraturreferansene er blitt vurdert til å gi relevante bidrag og til å belyse et komplekst, sosial-teoretisk og fenomenologisk felt - selv om også andre referanser kunne vært anvendbare - samtidig som de kan brukes til å belyse en del av dette feltet som relaterer seg til undervisningspraksis i kroppsøving.

\section{Om patisk kunnskap og tolkning}

Læreren kan bruke patisk kunnskap for å tolke og forstå elevens situasjon og læringsprosess i kroppsøving (Standal, 2015). Patisk kunnskap henviser til en intersubjektiv forbindelse mellom lærer og elev, og til begrepene sympati og empati. Utøvelse av patisk kunnskap kan forstås som en form for sosial kyndighet i kroppsøvingsundervisningen, som innlemmer lærerens sympati og empati overfor eleven. Denne sosiale kyndigheten kommer til uttrykk i ulike undervisningsstiler, situasjonsvurderinger og -bedømminger i timene, samt i relasjonelle ferdigheter i den sosiale interaksjonen med eleven. Undervisningsstiler er individuelle undervisningsmåter, som kan variere relativt mye i kroppsøving, men som kan ha bestemte hensikter overfor eleven, ikke minst med tanke på den enkelte elevs opplevelse av aktivitetene, erfaring og læring. Situasjonskyndighet er evne til vurdering, bedømmelse og håndtering av situasjoner der eleven er involvert, og som gjerne engasjerer lærerens praktiske dømmekraft i undervisningsprosessen. Relasjonell ferdighet brukes i ulike kommunikasjonssituasjoner med eleven, og innsikt i det relasjonelle forholdet til eleven erfares og utvikles som del av den sosiale interaksjonen læreren og eleven skaper sammen. Denne innsikten kan også gi pekepinner til å forstå elevens opplevelse av bevegelsesaktivitet i kroppsøving.

Annen forskning, som er foretatt med utgangspunkt i teori om kroppsøvingslærerens læring av faglig og didaktisk kunnskap, viser at læreres evne til å tolke elevens bevegelsesaktivitet og -opplevelse utvikles særlig gjennom praktisk undervisningserfaring, og at evnen til persepsjon og tolkning sammenveves med annen relevant faglig og didaktisk kunnskap (Schempp, 1993; Rovegno, 2003; Tsangaridou, 2006). Lærerens kjennskap til elevens følelser, erfaringer og opplevelse er en viktig del av det didaktiske kunnskapsgrunnlaget, samtidig som det utgjør et integrerende element i den profesjonelle kunnskapen og profesjonsutøvelsen (McCaughtry, 2004). Det vil gjerne være gunstig å forstå dybder i elevens bevegelsesaktivitet og -opplevelse for at elevens læringsprosess skal bli framgangsrik.

\section{Tidsmessig struktur i tolkningsprosessen}

Innenfor en kroppsfenomenologisk teoriramme kan lærerens tolkningsprosess analyseres og forstås ved å belyse ulike tidshorisonter i menneskets bevissthet (Steinsholt, 
2004; Gallagher og Zahavi, 2008). Menneskets bevissthet om tid lar ting som hører fortid, nåtid og framtid flyte sammen, og mennesket forholder seg til andre i meningsfulle prosesser som foregår over tid. Disse prosessene fører som regel fram til noe. Fenomenologer, blant andre Husserl (1859-1938) og Merleau-Ponty, delte innsikten om at menneskets tidsbevissthet har en retensjonal-protensjonal struktur (Steinsholt, 2004). Med dette menes en struktur som inneholder fortid, nåtid og framtid. Dette innebærer at den tidsmessige strukturen er bevissthetens mest grunnleggende form, som er med på å konstruere erfaringen, av det som varer og av det som endrer seg. Den indre tidsbevissthet er en pågående flyt der det som er foran akkurat nå, erfares mot en bakgrunn knyttet til det som nettopp har vært og det som vil komme i nær framtid. Et hvert nytt øyeblikk er med andre ord knyttet til det som nettopp har vært og det som snart kommer til å skje på en nær og indre måte.

Fortid, nåtid og framtid kan dermed forstås som gjensidig gjennomtrengende tidsmessige horisonter i lærerens bevissthet som omhandler elevens aktivitet og opplevelse $\mathrm{i}$ kroppsøving, erfaringen av denne, og til sist tolkningen av aktiviteten og opplevelsen. Det er ikke et spørsmål om å legge sammen erindringer for å finne en kommende fremtid, ettersom fremtid og fortid sammen konstituerer erfaringens dynamiske egenart, eller erfaringens bevegelighet. Den nære fortid vil forme seg etter hvert som at tiden forløper, fordi den vil bli betraktet mot et bakteppe av tidligere nå-situasjoner og mer presist forventede fremtider. En slik utvikling gjennom tiden endrer fortidens tilhørende relasjoner til andre deler av erfaringen, det vil si fortiden endrer sin betydning (Steinsholt, 2004). Dette betyr at når læreren i kroppsøving legger merke til, tolker og forstår elevens aktivitet og opplevelse i kroppsøvingstimene, betraktes det som foregår slik dette utvikler seg over tid, bestående av både fortid, nåtid og framtid.

\section{Interaksjon om og i bevegelsesaktivitet}

Det spesielle som utspiller seg i denne interaksjonen, er at den foregår om bevegelsesaktivitet og noen ganger $i$ bevegelsesaktivitet. Med dette menes interaksjon som foregår mens bevegelsesaktivitet pågår, det vil si at læreren kommuniserer med eleven om aktivitetene samtidig som eleven er bevegelsesaktiv, men også kommunikasjon $i$ selve aktiviteten, når elev og lærer begge er i aktivitet og deltagere på linje med hverandre (Lyngstad, 2014). Hele tiden vil interaksjonen være preget av en kroppslig dimensjon, og full av mening, fordi kroppslig bevegelse i seg selv er full av mening (Arnold, 1979).

Læreren fanger imidlertid ikke opp elevens bevegelsesaktivitet og -opplevelse bare gjennom å observere elevens aktivitet. Dette kan også gjøres gjennom talespråket og direkte, verbal dialog med eleven selv. Hvis en elev for eksempel har vansker med å lære en ferdighet i kroppsøvingstimen, kan det være mulig å få rede på elevens bestrebelser gjennom spørsmål, dialog og direkte tale med den det gjelder. I en diskusjon om elevens bevegelseslæring vil det være viktig å ha klart for seg at evnen til å forstå elevens verbale utsagn og muntlige fortellinger bidrar til en ofte nyansert forståelse av hva eleven erfarer - og også lærer - i kroppsøvingstimene (Lyngstad, 2014). 
På den annen side kan både lærer og elev erfare at sosial interaksjon, der bevegelsesaktivitet står sentralt, kan inneholde et instrumentelt - og ikke-verbalt - bevegelsesspråk. I dette språket uttrykkes også meninger, da først og fremst i de situasjoner der disse bevegelsene skapes og har en funksjon (Arnold, 1979). Denne typen kommunikasjon er meningsfull i den utstrekning kroppslig bevegelse overbringer det som avsender har til hensikt å overbringe, og at dette blir forstått av mottaker. Det forutsettes at både avsender og mottaker har felles forståelse for hva kroppslige uttrykksog bevegelsesmåter betyr, eller i hvert fall har omtrent samme forståelse. Hvis ikke vil kommunikasjonssituasjonen være vanskelig. Partene i kommunikasjonen vil være avhengig av et felles kodesystem, ettersom interaksjonen vil være preget av relativt mange kompliserende faktorer. Spesielt gjelder dette i forhold til emosjoner og tilstander hos mennesker:

Clearly, if a high degree of correspondence is to be achieved between what was intended by the sender and what is grasped by the receiver, especially in relation to such complex states as feelings and moods, then both the expressive powers of the former and the interpretive abilities of the latter, must stem from a common ground into which each has been initiated (Arnold, 1979, s. 67).

Kroppslig bevegelse kan være en rik ressurs for kommunikasjon mellom mennesker, eksempelvis mellom lærer og elev, til tross for at de språklige kodesystemer ikke er like godt utviklet i et «bevegelsesspråk» som i talespråket, ifølge Arnold. Årsaken til dette er at kroppslig bevegelse, gester, signaler og tegn, "whether 'given' or 'given off', whether liked or disliked by the observer and whether or not understood by him provide, whether he knows it or not, much of the life-world out of which he learns about and reacts to other people» (Arnold, 1979, s. 64). Menneskers livsverden åpnes for andre gjennom kroppslig bevegelse, og andre gis innsikt i livsverden gjennom persepsjon og tolkning av andres bevegelsesaktivitet.

Det eksisterer med andre ord ikke noe skarpt skille mellom stumme kroppslige bevegelser og talespråket innenfor en kroppsfenomenlogisk teoriramme, men heller sammenhenger. Innenfor denne rammen kan det tenkes at stumme kroppslige bevegelser og talespråk er sammenvevd med en uoppløselig innbyrdes tråd. Dette betyr at en elevs verbale utsagn i en kroppsøvingstime ikke bør fortolkes løsrevet fra ledsagende kroppslige bevegelser, ei heller motsatt, at kroppslig bevegelse fortolkes løsrevet fra eventuelle tilhørende verbale utsagn. Uttrykksmåtene må ses i sammenheng. I tilknytning til interaksjonen mellom lærer og elev, betyr dette at læreren møter eleven, hvis uttrykk er i en og samme sak både stumme kroppslige bevegelser og verbale utsagn, og det vil være lærerens oppgave å ta med begge deler i tolkningen av elevens aktivitet og opplevelse i kroppsøvingstimene.

Samtidig er det viktig å ha klart for seg at elevens bevegelsesaktivitet er nært forbundet med sine historiske omstendigheter, som nevnt tidligere, og befinner seg i midten av noe som har en begynnelse og som beveger seg i retning av noe (Gallagher \& Zahavi, 2008). Læreren vil se eleven innenfor en ramme av historie som lages av læreren og eleven selv i tid og rom. Historiene er ikke først og fremst om 
hva som foregår i elevens eller lærerens hode, men om hva som foregår i deres felles, delte verden (Lyngstad, 2014), og om hvordan både elev og lærer forstår og responderer på det som foregår i denne verden, som er preget av kroppslig bevegelse (Lloyd \& Smith, 2006).

\section{Fornemmelse og før-refleksivitet}

Lærerens erfaring av elevens bevegelsesaktivitet kan altså finne sted innenfor et romlig nå, hvor fortidens, samtidens og fremtidens horisonter bakes inn mot et forventet mål for eleven. For å utdype dette nærmere, vil jeg se nærmere på lærerens refleksive bevissthet omkring elevens aktivitet, som vokser omstendelig sammen med lærerens fornemmelse av elevens aktivitet ut fra elementer i egen erfaring. Her kommer dessuten begrepet vane inn i bildet (Steinsholt, 2004). Vaner som har avleiret seg i lærerens yrkesliv, kanskje over lang tid, hjelper til å ta stilling til hva elevens aktivitet betyr. Dette foregår ved at læreren "går opp» i elevens handlinger og fanger opp handlingenes endepunkt gjennom egne handlinger, som kan være relativt vanemessige $i$ kroppsøvingstimene, før læreren på en refleksiv måte har grepet situasjonen (Steinsholt, 2004). Før-refleksivitet betegner dette fenomenet. Et eksempel på vanemessig handling kan være undervisningsmåter som er godt innarbeidet over lang tid i kroppsøvingstimene.

For å skjønne hvordan den refleksive bevissthet vokser omstendelig sammen med fornemmelsen av elevens aktivitet ut fra elementer i egen erfaring, tjener det hensikten å reflektere over hva begrepet kroppslig subjekt innebærer. Kroppen er hele tiden nærværende innenfor lærerens erfaring, og det er som kropp læreren kan erfare hva en elev holder på med i timen. I tillegg utvikles den tidsmessige struktur mot kroppen som bakgrunn, som kontinuerlig holder sammen erfaringsfeltet og bildet av eleven. Motsatt er utviklingen av elevens aktivitet og handlinger også en betingelse for lærerens kunnskap om egen virksomhet. På denne måten erfarer læreren elevens utvikling ut fra egne handlinger som bakgrunn, og persepsjonen av hva eleven holder på med er godt festet i læreren selv og oppfatningen av tiden.

Den før-refleksive foregripelse av elevens bevegelsesaktivitet har på denne måten karakter av en forestilling av hvor læreren må være neste gang for å kunne koordinere sine handlinger sammen med elevens aktivitet. Og mens denne prosessen pågår, utvides også innsikten i elevens aktivitet, blant annet omkring følelser. Noen lærere vil fornemme hvor de skal være og hva de skal gjøre, og det kan tenkes at de ikke trenger å bruke mye tid for å koordinere sine handlinger sammen med elevens handlinger heller (Lyngstad, 2014). Denne fornemmelsen av hvor eleven vil være, fremstår ikke som et klart bilde, men det kan føles, og det kan foregripes. Dessuten kan begrepet kroppslig resonans bidra til forståelse på dette området (Fuchs, 2016). Underveis i denne prosessen indikerer kroppslige signaler at lærerens handlinger får mottakelse hos eleven og fanges opp av eleven. Læreren orienterer seg samtidig mot eleven, og mer og mer fletter lærerens handlinger seg sammen med elevens handlinger. 


\section{Lyngstad}

Det er et fenomenologisk drag over denne prosessen, $i$ form av den dialektiske strukturen i interaksjonen mellom lærer og elev. Vekslingene mellom lærerens didaktiske handlinger og elevens respons, som er bevegelsesaktivitet, kan være rytmiske, og prosessen flyter jevnt. Kanskje flyter den hurtig av sted. Men den kan også være problemfylt, med rytmebrudd og treg flyt. I den problemfrie prosessen leder det fram til at eleven når læringsmål ganske raskt, og læreren oppfatter også dette, mens den problemfulle prosessen innebærer lenger tid før eleven når sine læringsmål, om de i hele tatt nås. Tilsvarende kan læreren da erfare usikkerhet omkring elevens læring og bevegelsesopplevelse. Denne egenskapen hos læreren til å fornemme kvalitative trekk ved elevens aktivitet gjennom egne handlinger eksisterer gjerne når læreren har erfaringer fra tilsvarende situasjoner som elever befinner seg i, det vil si også å kunne utføre kroppslig bevegelse av samme type selv (Lyngstad, 2013).

Dette erfaringsgrunnlaget kan imidlertid variere blant lærere, fordi de har ulik biografi og historie. Dersom læreren har manglende bevegelseserfaring på de områder som kroppsøvingsundervisning omhandler, så er det fare for at han eller hun $\mathrm{i}$ dårligere stand til å leve seg inn i aktiviteter som eleven skal lære i denne undervisningen, og derav til å forstå ulike erfaringer og opplevelser for eleven i forbindelse med aktivitetsutøvelsen. Motsatt vil allsidig og mye bevegelseserfaring gi læreren godt utgangspunkt for innlevelse i læringsaktivitetene til eleven og til å forstå hva eleven erfarer og opplever i forbindelse med bevegelsesaktiviteten.

\section{Intersubjektivitet}

Videre vil jeg se nærmere på begrepet intersubjektivitet i denne forbindelse. Dette begrepet er blitt berørt tidligere i artikkelen, i forbindelse med kommunikasjon gjennom et bevegelsesspråk (Arnold, 1979) samt lærerens patiske kunnskap (Standal, 2015), men ikke utdypet nærmere. Lærer og elev kan bli parter i en dynamisk sensoriskmotorisk og affektivt system som forbinder partene gjennom bevegelseshandlinger og responser på disse handlingene, eller gjennom inter-kroppslig resonans (Fuchs, 2016). Intersubjektivitet kan også omhandle empati og intensjonalitet fra begge sider, eller erfaring av andre og innlevelse $\mathrm{i}$ andres livsverden gjennom en imaginær overflytting av selvet til andres posisjoner (Crossley, 1996). Det kan til sist omhandle at menneskelig intersubjektivitet svinger mellom to hovedformer, en radikal og egologisk form.

En radikal form for intersubjektivitet karakteriseres ved sterk selvsentrering og mangel på åpenhet overfor andre. Noen ganger er et menneske helt oppslukt i seg selv og for engasjert til å være bevisst på andre mennesker. Andre ganger kan mennesket raskt bli klar over andre i et sosialt miljø, og en vil gå inn i en interaksjon med de andre. Da blir begge parter identifiserbare deler av den sosiale erfaringen som partene skaffer seg (egologisk intersubjektivitet). Samtidig menes også at:

Each lived body with its sensorimotor body schema reaches out, as it were, to be extended by the other. This is accompanied by a holistic impression of the interaction partner and his current state (for example his anger), and by a feeling for 
the overall atmosphere of the shared situation (for example a tense atmosphere)

(Fuchs, 2016, s. 199).

Teori om selvet kan forklare egologisk intersubjektivitet nærmere. Selvet er grunnlagt i den sosiale verden, og mennesket utvikler selvet gjennom refleksive prosesser. Et menneske kan se seg tilbake $i$ tid, se seg fra utsiden, eller som andre ville se seg selv. Denne refleksive prosess er mulig gjennom den sosiale interaksjonen med andre. På denne måten erfarer både lærer og elev den andre i den sosiale konteksten som kroppsøving er, og de impliserte blir sosiale vesener for hverandre. De andre blir personer som hver enkelt fortolker handlingene til. Fordi praktisk, fysisk aktivitet står sentralt i kroppsøvingstimene, tolker læreren elevens aktivitet innenfor en praktisk aktivitetskontekst, som reguleres av både formelle regler ved aktiviteter og spill i kroppsøvingen, og uformelle, sosiale regler i forbindelse med dette (etter Arnold, 1979). Dette kan skje ettersom elevens bevegelsesaktivitet ikke svever fritt i luften, men finnes $i$ verden, underlagt sosiale symboler og regler som gjelder i denne verden, sammen med kroppene som manifesterer dem (Gallagher \& Zahavi, 2008).

Andre aspekter kan være at tolkningen foregår på basis av lærerens historiske kjennskap til eleven, som tidligere kan ha vist lignende handlinger, eller at generell kjennskap til eleven og inntrykk fra andre fag og undervisningssituasjoner trekkes inn i tolkningen av handlingene i kroppsøving (Lyngstad, 2013). Dette vil gjelde i de tilfeller der læreren underviser eleven i flere fag enn kroppsøving, noe som ikke er så uvanlig for en del lærere.

Samtidig er det slik at hver elev har ulike kroppslige gestaltninger og aktivitetsmønstre i kroppsøving. Variasjonen i aktivitetsmønstre hos elevene kan dermed være stor. Men, dette trenger ikke være et stort problem for å kunne forstå meninger med elevens aktivitet, ettersom den sosiale konteksten hjelper til å favne denne variasjonen og til å forstå betydningene av elevens bevegelsesaktivitet, til tross for at disse er forskjellige. Læreren kan for eksempel skille mellom aktivitet som bare blir utført fordi eleven blir bedt om det av læreren, og aktivitet som til forskjell kommer av seg selv, fordi aktiviteten er indre motivert.

Det som foregår i kroppsøving er med andre ord et komplekst vekselspill mellom lærerens handlinger og elevens respons og aktivitet. Dette impliserer tolkninger av elevens aktivitet og -opplevelse. Gjennom egne handlinger fanger læreren opp elevens erfaring og opplevelse. Elevens aktivitet er samtidig respons på faglige oppgaver som læreren gir til eleven, og virker som tilbakemeldinger på lærerens didaktiske strategier, på samme tid som lærerens atferd foregår ut i fra elevens responser og - i de fleste tilfeller - har til hensikt å fremme læring hos eleven (bortsett fra når eleven må gjennomføre «straffeeksersis» i timen, (Aasland, et. al, 2016)). Hele tiden foregår persepsjon og tolkning av hverandres handlinger.

\section{Kortfattet og upålitelig refleksjon}

Etter at noe har skjedd i kroppsøvingen, kan læreren umiddelbart reflektere over det som har skjedd. Et visst problem oppstår imidlertid i forbindelse med denne 


\section{Lyngstad}

refleksjonen. Som regel vil muligheten til å reflektere begrenses, fordi læreren har knapt med tid. Sosial interaksjon i kroppsøving skjer raskt, og det er som oftest kort tid til å tenke over hva som egentlig har skjedd før det har skjedd noe nytt. Dessuten er det vanligvis mange elever involvert i kroppsøvingsundervisningen, som skaper aktivitet og handlinger mot mange forskjellige mål og bevegelsesprosjekter på samme tid. Den form for refleksjon som når læreren midt i en interaksjon med eleven, kan derfor være i øyeblikks form, og kortfattet og delvis upålitelig. Lærerens fornemmelse av hvor eleven vil være og evnen til å foregripe dette, vil kunne svekkes. Det læreren husker fra disse øyeblikkene, fremstår ofte som rekonstruert - i den forstand at de reelle situasjonene ikke gjenkalles presist, men blandes med gjetninger om hva som skjedde (Steinsholt, 2004). Det læreren tar med seg fra situasjonene og gjør til gjenstand for refleksjon i ettertid, kan med andre ord være usikkert, og ha en karakter av å være flytende. I neste omgang vil dette få betydning for tolkningen av elevens bevegelsesaktivitet og-opplevelse.

Av og til kan det imidlertid være slik at lærere umiddelbart fanger opp elevens aktivitet og -opplevelse og forstår betydningen av denne, for eksempel når betydningen av det eleven holder på med ikke kan skilles fra lærerens egen virksomhet, men er vevd inn i virksomheten som en sentral tråd. Andre ganger kan det være slik at elevens handlinger ikke kan knyttes direkte til lærerens handlinger her og nå og fremtidige virksomhet. Da blir det vanskeligere å tolke og forstå hva eleven holder på med og opplever, og kanskje også ønsker å oppnå. Den sosiale interaksjonen kan føre til at læreren forstår hva eleven opplever ut fra responser og handlingsmønster, noen ganger uten at det er nødvendig å snakke med eleven, mens det andre ganger er vanskeligere, som nevnt tidligere (Lyngstad, 2010). For eksempel kan læreren skjønne at et blikk, som en elev sender til læreren i forbindelse med at hun eller han gjør en eller annen kroppslig øvelse, betyr bestemte ting, for eksempel glede eller skuffelse, fordi læreren er der i elevenes virksomhet og er åpen mot eleven. Motsatt kan unngåelsesstrategier og manipuleringsteknikker (Ommundsen, 2004) fra eleven gjøre det vanskelig å forstå hva eleven opplever og tenker.

Læreren kan dermed relatere seg til elevens livsverden og fornemme elevens opplevelse, dersom eleven er åpen overfor læreren. Når en elev for eksempel jubler etter å ha fått til en øvelse, kan læreren skjønne at dette er fordi eleven er glad. Et annet eksempel er at læreren kan forstå at elevens høge innsats kommer av at eleven liker å være fysisk aktiv og har lyst til å bevege seg. Motsatt kan læreren forstå at lav aktivitet kan være på grunn av lav motivasjon og mistrivsel. Læreren trenger ikke fundere på hvilke tanker og følelser som er gjemt inne i eleven, men kan se opplevelse direkte i kroppslige uttrykk og bevegelser. Eksempelvis når en elev uttrykker smerte etter å ha falt ned fra balansebommen i gymsalen, betyr det at eleven har det vondt. Læreren kan dermed tolke elevens følelse ganske enkelt, og skjønne hva situasjonen betyr, uten stor fare for feiltolkning.

Men, dette betyr ikke at læreren erfarer elevens smerter, eller andre følelser for den saks skyld, som om vedkommende var eleven selv. Læreren forstår at smerteuttrykkene 
betyr at eleven har det vondt, men erfarer ikke smertene som eleven selv gjør det. Læreren erfarer smertene i egenskap av å være en annen person. Dette har sammenheng med at læreren forstår elevens opplevelse gjennom den tilgang han eller hun får til opplevelsen som andre-person, ikke første-person, som er eleven selv. Gallagher og Zahavi (2008, s. 187) uttrykker ganske klart i forbindelse med dette at «the second [...] person access to another person differs from the first-person access to his own experience». Ei heller er andre menneskers bevissthet tilgjengelig på samme måte som ens egen bevissthet. Innlevelsen må altså avgrenses på dette punktet. Den kan aldri bli total. Dersom et menneske har samme tilgang til andres bevissthet som sin egen, vil de andre opphøre med å være andre, og i stedet bli del av en selv, noe som er utenkelig.

Men denne forskjellen er ikke en ufullkommenhet eller mangel. Den er derimot konstitusjonell i videre arbeid med teoriutvikling på området. Det er nettopp forskjellen som gjør at læreren kan erfare eleven som en annen, og ikke ende opp med å erfare eleven som seg selv. Dette resulterer i en interessant og lovende mulighet for dypere innsikter i teorifeltet. Et perspektiv som belyses, er at lærerens tolkning av elevers bevegelsesaktivitet og -opplevelse er en krevende balanseøvelse for læreren også, selvsagt på et helt annen måte enn for eleven på balansebommen. På den ene side vil det være uklokt å overvurdere forskjellen mellom en selv og eleven, fordi dette vil sette læreren fast i en posisjon som neglisjerer eget subjekt og som gjør at læreren ikke tør å tillegge mening til hendelser og situasjoner omkring elevens aktivitet i hele tatt. På den annen side vil det være uklokt å undervurdere forskjellen, fordi dette er urettferdig overfor elevens annerledeshet. Det kan imidlertid tenkes at læreren tolker og forstår elevens opplevelse på en eller flere slags måter. Læreren kan for eksempel forstå at eleven som falt ned fra bommen opplever fysisk smerte og føler vondt, dessuten at eleven var skuffet over å mislykkes med oppgaven, som var å balansere på bommen. Og kanskje forstås, som en ytterligere dimensjon, at eleven erfarte at å mislykkes også var et sosialt «fall», ettersom hendelsen også ble lagt merke til av andre som var tilstede. Flere lag med mening kan altså legges til. Et annet perspektiv kan være at lærer og elev vil ha gjensidig nytte av hverandre for at begge parters oppgaver skal løses tilfredsstillende. Dersom eleven skal makte å fullføre sine framtidige prosjekter, for eksempel ny bevegelseslæring, har eleven nytte av at læreren gir respons og læringsfremmende tilbakemeldinger, og motsatt har læreren nytte av at eleven gir respons for at lærerens didaktiske planer i framtid skal kunne realiseres.

\section{Konklusjon}

Forskning på tolkning av elevens bevegelsesaktivitet og -opplevelse ved bruk av kroppsfenomenologiske termer har potensial til fordypet innsikt i lærerens tolkningsarbeid i undervisningen og bidrar til teori om lærerrollen og undervisning i faget. Kroppsfenomenologiske aspekter som jeg har belyst, viser at lærere fornemmer hvilke bevegelsesprosjekter elevene befinner seg i og ønsker å gjennomføre, og gjennom egne 
handlinger fanger læreren opp og får tak på hva eleven opplever og erfarer. Læreren koordinerer egne didaktiske handlinger i tråd med elevens bevegelsesaktivitet og persiperer, tolker og forstår elevens aktivitet og -opplevelse gjennom egne handlinger $\mathrm{i}$ undervisningen. Trådene mellom egne og elevens handlinger kan imidlertid bli løsere sammenvevd noen ganger, fordi den sosiale interaksjonen i kroppsøving skjer så raskt at det lærere husker fra timene, blandes med gjetninger. Den sosiale interaksjonen kan med andre ord bestå av faktorer som gjør tolkningsprosessen kompleks, og potensielt krevende. Læreren kan dessuten selv bidra til å skape utydelige handlinger hos eleven. En annen kompliserende faktor er at elevens handlinger kan bestå av aktiviteter mot flere bevegelsesprosjekter og -mål på samme tid.

En annen dimensjon er at det læreren tar med seg fra interaksjonen og gjør til gjenstand for refleksjon i ettertid, kan ha karakter av å være flytende. Erindring om hva som skjedde, kan preges av gjetning av hva som skjedde. Samtidig må teori, som har som ambisjon å belyse lærerens perseptuelle felt og lærerens innlevelse, avgrenses på et viktig punkt, fordi innlevelsen kan aldri bli total. En person kan ikke ende opp med å bli en annen person. I forbindelse med dette må også den patiske kunnskap hos læreren avgrenses. Forskjellen mellom lærer og elev er imidlertid ikke en ufullkommenhet eller mangel, den er derimot konstitusjonell og til nytte i det videre arbeid med tolkning og innlevelse, blant annet i termene kroppslig resonans (både intra- og inter-kroppslig) og kinestetisk sammenfletting, samt nyttig også til å utdype et didaktisk perspektiv i kroppsøvingsundervisningen; om blant annet betydningen av grundighet i undervisningsplanleggingen, samt sosial kyndighet som bidrar til framgang for eleven i kroppsøvingstimene.

\section{Referanser}

Aasland, E., Walseth, K. \& Engelsrud, G. (2016). The changing value of vigorous activity and the paradox of utilising exercise as punishment in physical education. Physical Education and Sport Pedagogy, DOI: 10.1080/17408989.2016.1268590.

Arnold, P. J. (1979). Meaning in Movement, Sport and Physical Education. London: Heinemann.

Crossley, N. (1996). Intersubjectivity. The fabric of social becoming. London: Sage publications.

Fuchs, T. (2016). Intercorporeality and Interaffectivity. Phenomenology and Mind, 11, 194-209. DOI: 10.13128/ Phe_Mi-201

Gallagher, S. \& Zahavi, D. (2008). The Phenomenological Mind. An introduction to philosophy of mind and cognitive science. London: Routledge.

Hagen, P-M, Aune, O. \& Lyngstad, I. (2014). Skjuleteknikk i kroppsøving. Tidsskriftet FoU i praksis, 8(1), 59-76. Lloyd, R. J. \& Smith, S. J. (2006). Interactive Flow in Exercise Pedagogy. Quest, 58, 222-241.

Lyngstad, I. (2010). Bevegelsesgleden i kroppsøving. I: M. Nygård \& M. Stene (red.), Forskning Trøndelag - 2010 (s. 65-78). Trondheim: Tapir Akademisk forlag.

Lyngstad, I. (2013). Profesjonell kunnskap i skolens kroppsøvingsfag. Teoretisk og empirisk belysning $i$ et fenomenologisk og praksisrelatert perspektiv. Trondheim; Norges Teknisk-naturvitenskapelige universitet. Avhandling for graden $\mathrm{PhD}$.

Lyngstad, I. (2014). A shared secret. Sport, Education E Society, 19(2), 153-167.

Lyngstad, I. (2016). Understanding pupils' hiding techniques in physical education. Sport, Education E Society, 21, 8. DOI:10.1080/13573322.2014.993960

McCaughtry, N. (2004). The Emotional Dimensions of a Teacher's Pedagogical Content Knowledge: Influences on Content, Curriculum, and Pedagogy. Fournal of Teaching in Physical Education, 23, 30-47.

Merleau-Ponty, M. (1994). Kroppens fenomenologi. Oslo: Pax Forlag. (Phénoménologie de la perception, 1945.) 


\section{Fenomenologisk forståelse av elevens bevegelsesaktivitet}

Ommundsen, Y. (2004). Self-handicapping related to task and performance-approach and avoidance goals in physical education. Fournal of Applied Sport Psychology, 16, 183-197.

Orlikowski, W. (2010). Practice in research: phenomenon, perspective and philosophy. I D. Golsorkhi, L. Rouleau, D. Seidl \& E. Vaara, (red.), Strategy as practice. Cambridge: Cambridge University press, 23-33.

Rovegno, I. (2003). Teacher's Knowledge Construction. I S. Silverman \& C. Ennis (red.), Student Learning in Physical Education (s. 295-310). Champaign: Human Kinetics.

Schempp, P. (1993). Constructing professional knowledge: a case study of an experienced high school teacher. fournal of Teaching in Physical Education, 13, 2-23.

Standal, Ø. F. (2015). Phenomenology and Pedagogy in Physical Education. London and New York, Routledge.

Steinsholt, K. (2004). Hvordan kan jeg vite hva du holder på med? - et fenomenologisk blikk på erfaring, kropp, adferd og mening. I K. Steinsholt, Steinsholt LIVE. Trondheim: Tapir Akademisk forlag.

Swartling Widerström, K. (2005). Att ha eller vara kropp? Örebro: Örebro Universitet.

Tsangaridou, N. (2006). Teachers' knowledge. I D. Kirk, D. Macdonald \& M. O’Sullivan (red.), The Handbook of Physical Education (s. 502-515). London: Sage.

Utdanningsdirektoratet (2015). Lcereplan $i$ kroppsøving. Hentet 21.12. 2016 fra http://www.udir.no/ laring-og-trivsel/lareplanverket/finn-lareplan/\#kroppsøving

Østerberg, D. (1994). Innledning. I M. Merleau-Ponty, Kroppens fenomenologi. Oslo: Pax Forlag. V-XII. 